\title{
A new Culicoides (Diptera:Ceratopogonidae) of the subgenus Diphaomyia from Peru
}

\author{
Maria Luiza Felippe-Bauer ${ }^{+}$, Abraham G Cáceres* , Cristiane S Silva, \\ William Valderrama-Bazan**, Antero Gonzales-Perez***
}

\begin{abstract}
Departamento de Entomologia, Instituto Oswaldo Cruz-Fiocruz, Av. Brasil 4365, 21045-900 Rio de Janeiro, RJ, Brasil *División de Entomologia, Instituto Nacional de Salud, Ministério de Salud and Instituto de Medicina Tropical "Daniel A. Carrión", Universidad Nacional Mayor de San Marcos, Lima, Perú **Servicio Nacional de Sanidad Agraria, Ministério de Agricultura, Lima, Perú ***Centro de Salud Bagua Grande, Sub Región de Salud Bagua, Amazonas, Perú
\end{abstract}

A new species of Culicoides of the subgenus Diphaomyia, Culicoides jurbergi Felippe-Bauer, is described and illustrated based on female specimens collected biting man and with light traps in Peruvian Amazonia. The species is compared with its similar congener mirsae Ortiz.

Key words: Diptera - Ceratopogonidae - Neotropical bloodsucking midges - Culicoides (Diphaomyia) jurbergi sp.n. - Peru

The genus Culicoides Latreille presently contains 285 Neotropical species [271 are included in Borkent and Wirth (1997) and in Borkent and Spinelli (2000)]. It is poorly known in Peru with only 4 species originally described for this country and 13 more subsequently reported. Of the 285 Neotropical species, 11 belong to the subgenus Diphaomyia Vargas, none of them recorded from Peru. The purpose of this work is to describe and illustrate a new species of this subgenus from Peru, based on female specimens captured while biting humans or from light trap collections.

The terminology used is that employed in Culicoides papers by Wirth and Blanton for Panama (1959), the Amazon Basin (1973), and the West Indian (1974), as well as the atlas of wing photographs of Neotropical species by Wirth et al. (1988). All measurements are in micrometers, except those of the wings which are in millimeters.

\section{Culicoides jurbergi Felippe-Bauer, new species (Figs 1-8)}

Diagnosis - A species of the subgenus Diphaomyia very similar to $C$. mirsae Ortiz. The female can be distinguished by its greater size (wing length $0.92-1.05 \mathrm{~mm}$ ), palpal ratio (2.7-3.4), antenal ratio (0.92-1.12), $\mathrm{P} / \mathrm{H}$ ratio (1.00-1.21) and by the presence of sensilla coeloconica on the flagellomeres 1,8-13. Male unknown.

Female - Wing length $0.92-1.05(0.99, \mathrm{n}=14) \mathrm{mm}$; breadth 0.46-0.54 $(0.50, \mathrm{n}=14) \mathrm{mm}$.

Head - Brown. Eyes (Fig. 2) pubescent, broadly separated by distance of diameter of 1.5-2 ommatidia. Flagellum (Fig. 3) brown, with proximal 1/3 of flagellomeres 1-6 paler; flagellomeres with mean lengths of 37-29-32-35-35$35-35-37-48-48-53-56-80 \mu \mathrm{m}(\mathrm{n}=14)$; antennal ratio 0.92-

${ }^{+}$Corresponding author. E-mail: mlfbauer@ioc.fiocruz.br Received 5 October 2004 Accepted 12 January 2005
$1.12(1.03, \mathrm{n}=14)$; sensilla coeloconica on flagellomeres 1,8-13, one, rarely two on 1 and 13. Palpus (Fig. 4) brown; lengths of segments 21-61-80-24-24 $\mu \mathrm{m}$; 3rd segment slightly swollen distally, with a moderately deep sensory pit on distal portion; palpal ratio 2.7-3.4 $(3.0, \mathrm{n}=13)$. Proboscis long; $\mathrm{P} / \mathrm{H}$ ratio $1.00-1.21(1.09, \mathrm{n}=14)$; mandible with 20 teeth.

Thorax - Brown; without definite pattern in slide mounted specimens. Legs mostly brown; fore, mid femora with subapical, tibiae with subbasal pale bands; hind tibia slightly pale apically (Fig. 8); hind tibial comb (Fig. 7) with four spines, the one nearest spur longest. Tarsi (Fig. 6) pale, first tarsomere darkest. Wing (Fig. 1) with pattern as in photographs: membrane infuscated, pale spots small and definite; cell r5 with four small separated pale spots, one, round, lying on distal side of r-m crossvein, two well separated poststigmatic pale spots, the anterior one small, rounded, reaching wing margin, the posterior one transverse and located beyond 2nd radial cell, apical spot generally thin and transverse (Fig. 1a) not reaching wing margin or vein $\mathrm{M}_{1}$, sometimes large and rounder (Fig. 1b) or nearly obsolete (Fig. 1c); cell $\mathrm{m}_{1}$ with two rounded spots, distal most far from wing margin; cell $\mathrm{m}_{2}$ with 3 spots, one proximal to medial fork, 2nd distal to mediocubital fork, 3rd spot larger, rounded, in distal part of cell, but not reaching wing margin; cell $\mathrm{m}_{4}$ with small, round, pale spot nearly reaching wing margin; anal cell with a transverse, sinuous pale spot anterior of mediocubital fork, reaching wing margin, sometimes double (Fig. 1a) with a faint pale spot in anal angle and near the wing base; veins $\mathrm{M}_{1}$ and $\mathrm{M}_{2}, \mathrm{M}_{3+4}$ and $\mathrm{Cu}_{1}$ dark; macrotrichia sparse on distal half of wing, a few in base of cell $\mathrm{m}_{2}$ and anal cell; second radial cell with distinct lumen; costal ratio 0.58-0.62 (0.60, $\mathrm{n}=2$ ). Halter pale.

Abdomen - Brown. Two unequal sized ovoid spermathecae (Fig. 5) with well developed, short necks, measuring 45 by $32 \mu \mathrm{m}$ and 37 by $27 \mu \mathrm{m}(\mathrm{n}=14)$ respectively; long, slender rudimentary $3 \mathrm{rd}$ spermatheca and short, round sclerotized ring also present.

Male - Unknown. 

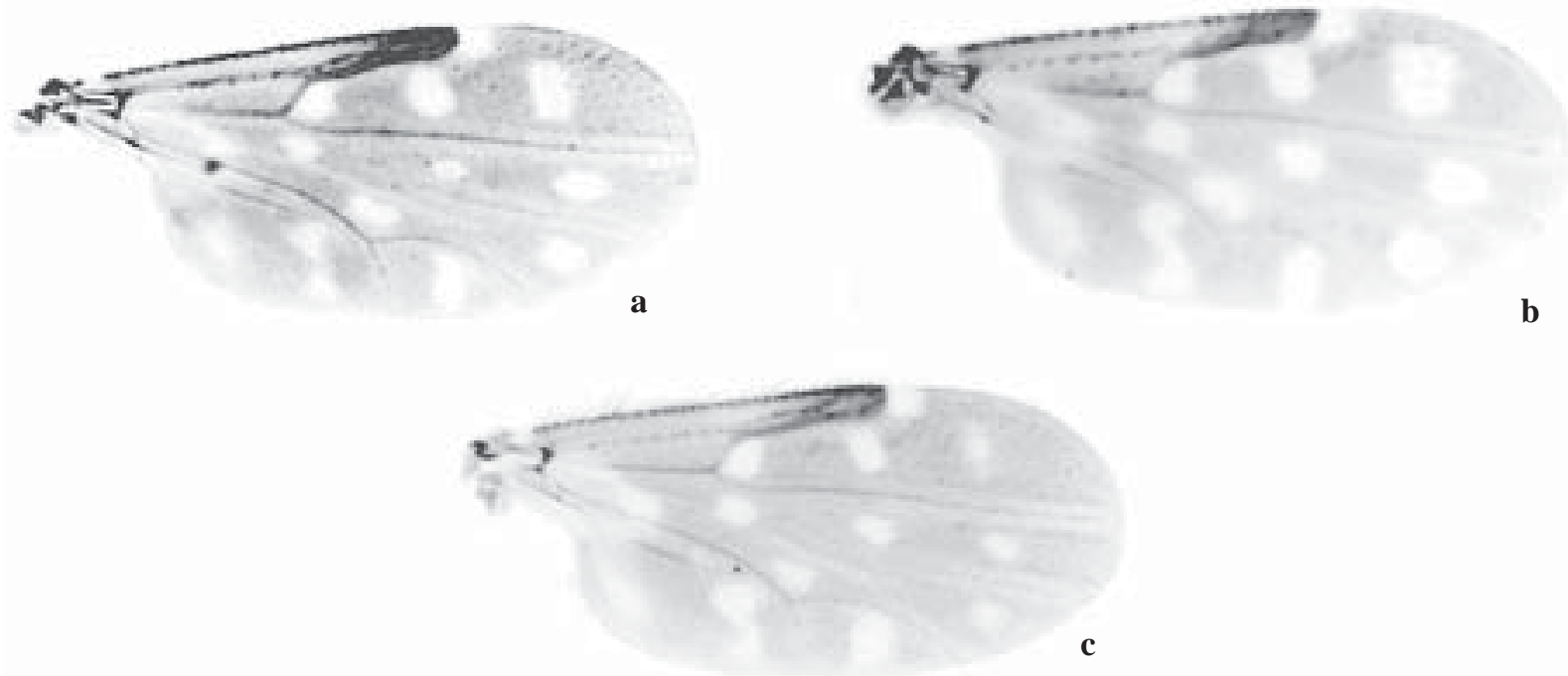

Fig. 1 a-c: variation in the pattern of female wings of Culicoides jurbergi sp.n.

Distribution - Peru (Departments of Amazonas, Cajamarca and Madre Dios).

Types - Holotype female, El Aserradero, Distrito de Jamalca, Provincia de Utcubamba, Departamento de Amazonas, PERU, 12.III.2002, biting human during 16:45-

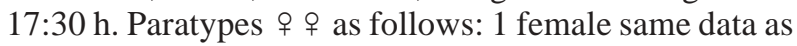
holotype; 4 females same data as holotype except 17.II.2002 biting human during 16:10-17:10 h., $06 . I V .2002$ biting human during 16:30-17:30; 12 females, San Antonio, Distrito de Cajaruro, Provincia de Utcubamba, Departamento de Amazonas, PERU, 15.VIII.2000 biting human during 13:00-13:30 h., 12.V.2001 biting human during 17:00-18:00 h., 13.V.2001 biting human during 18:0019:00 h., 12.V.2001 biting human during 17:00-18:00 h., 10.XI.2001 biting human during 17:00-18:00 h., 07.I.2002 biting human during 16:00-18:00 h., 24.II.2002 biting human during 08:00-09:00 h. Holotype (Dip. Cer. 413) and 9 paratypes (Dip. Cer. 414-422) deposited in Instituto Oswaldo Cruz, Rio de Janeiro, Brazil; 2 females from El Aserradero, 17.II.2002 biting human during 16:10-17:10 h, deposited in Museo de La Plata, La Plata, Argentina; 2 females (1 female from El Aserradero, 17.II.2002 biting human during 16:10-17:10 h. and 1 female from San Antonio 07.I.2002 biting human during 16:00-18:00 h) deposited in Faculdade de Saúde Pública, Universidade de São Paulo, São Paulo, Brazil; 2 females from San Antonio, 10.XI.2001 biting human during 17:00-18:00 h, deposited in Instituto Nacional de Salud, Lima, Peru; 2 females from San Antonio, 24.II.2002 biting human during 08:00-09:00 $\mathrm{h}$, deposited in Smithsonian Institution, US.

Additional material examined - After determination of the type material we have received additional specimens preserved in alcohol 70\%. These 98 females were deposited in IOC, as follows: 13 females, San Antonio,
Distrito de Cajaruro, Provincia de Utcubamba, Departamento de Amazonas, PERU, 05.VI.2001, biting human during 16:30-17:30 h; Ibidem 26 females, except 08.XII.2001; 32 females, Yungasuyo, Distrito de Lonya Grande, Provincia de Utcubamba, Departamento de Amazonas, PERU, VII.2001, biting human during 11:00-12:00 h; 12 females, Papayal Bajo, Distrito de Coipa, Provincia de San Ignacio, Departamento de Cajamarca, PERU, 13.II.2002, biting human during 17:00-20:00 h; 15 females, Santa Rosa, Distrito de Laberinto, Provincia de Tambopata, Departamento de Madre Dios, PERU, 7-8.VIII.2002, light trap 17:00-07:00 h.

Etymology - This species is named after Dr José Jurberg, who has led the development of the Department of Entomology for many years, and has provided kind support for workers of different fields of medical entomological research at the Instituto Oswaldo Cruz.

Discussion - C. jurbergi is a typical member of the subgenus Diphaomyia and closely resembles $C$. haematopotus Malloch, C. marinkellei Wirth and Lee, $C$. minasensis Felippe-Bauer, $C$. mirsae Ortiz, C. tarapaca Spinelli and $C$. ronderosae Spinelli and Borkent by the presence of a pale spot at $\mathrm{r}-\mathrm{m}$ crossvein lying entirely distal to the crossvein in cell $\mathrm{r} 5$. Regarding the peculiar aspect of the wing, it is indistinguishable from $C$. mirsae from which it differs by its larger palpal ratio 2.7-3.4 (2.1 in mirsae), antennal ratio $0.92-1.12$ (0.70 in mirsae), $\mathrm{P} / \mathrm{H}$ ratio 1.00-1.21 (0.84 in mirsae) and the presence of sensilla coeloconica on flagellomeres 1,8-13 (1,6-8 in mirsae).

\section{ACKNOWLEDGEMENTS}

To the coordinators of Centro de Salud de Bagua Grande, Sub Region de Salud Bagua, Amazonas and to Laboratorio Referencial de la Direccion de Salud Madre de Dios, for personal support with field work. 


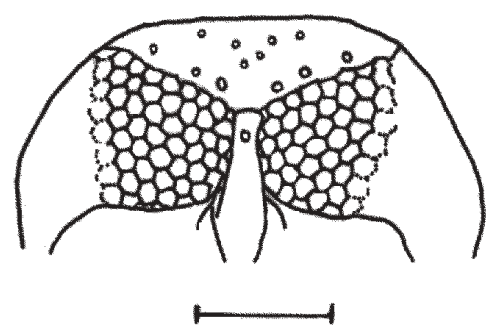

$0.1 \mathrm{~mm}$

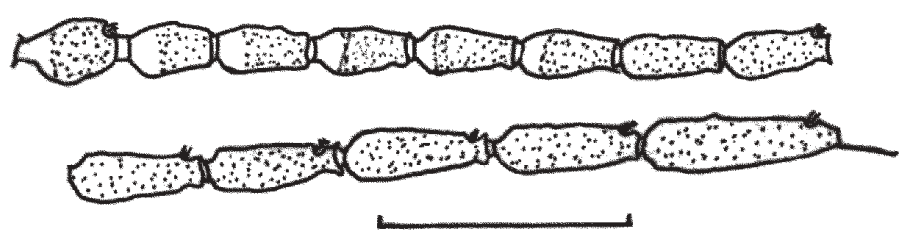

$0.1 \mathrm{~mm}$
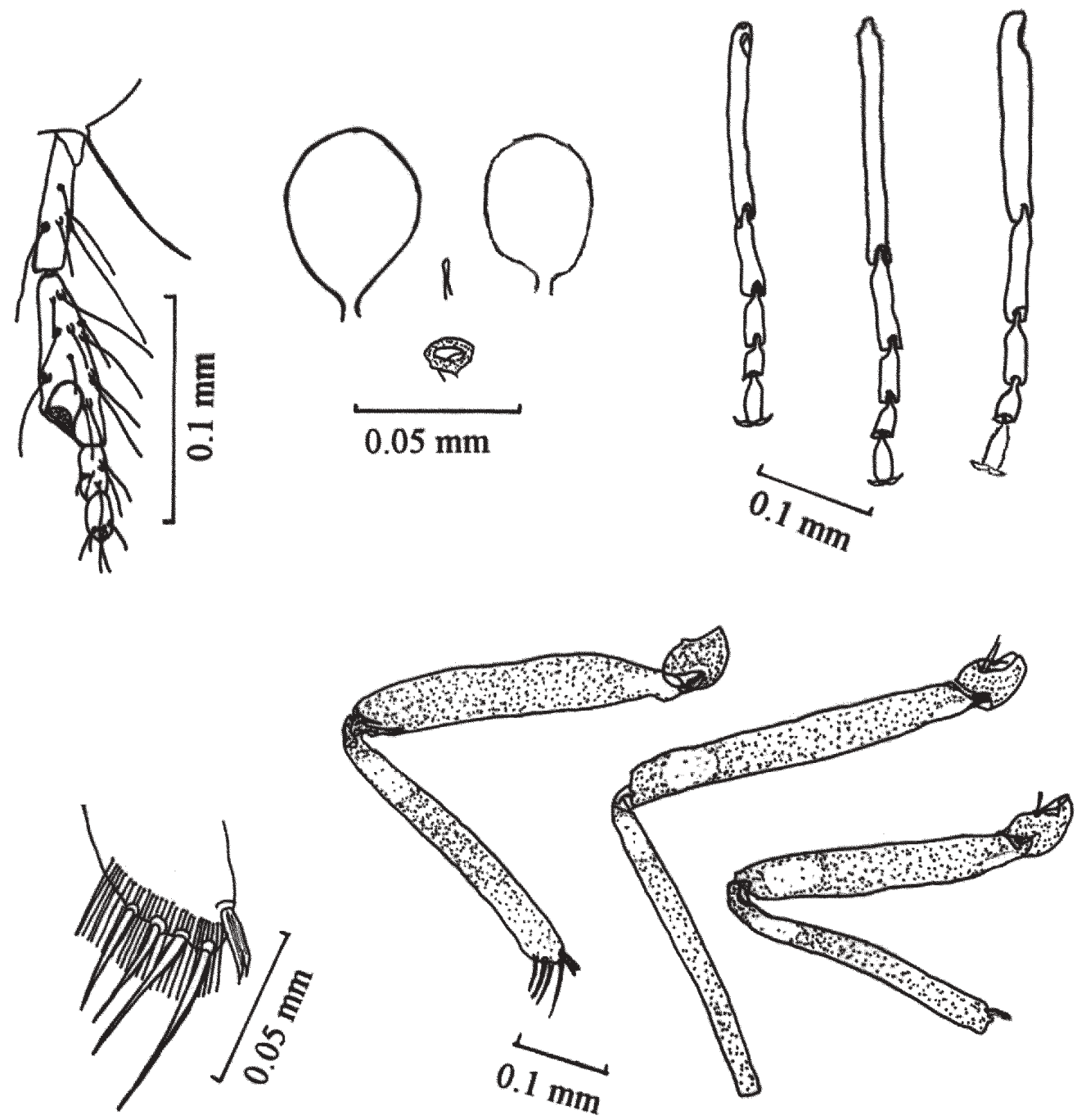

Culicoides jurbergi sp.n., female. Fig. 2: dorsal portion of head capsule, in anterior view. Fig. 3: antenna. Fig. 4: palpus. Fig. 5: spermathecae. Fig. 6: tarsi (left to right) fore, mid, and hind. Fig. 7: hind tibial comb. Fig. 8: legs (left to right) hind, mid, and fore.

\section{REFERENCES}

Borkent A, Spinelli GR 2000. Catalog of the New World biting midges South of the United States of America (Diptera: Ceratopogonidae). Contr Ent Inter 4: 1-107.

Borkent A, Wirth WW 1997. World species of biting midges (Diptera:Ceratopogonidae). Bull Am Mus Nat Hist 233: 1257.

Wirth WW, Blanton FS 1959. Biting midges of the genus Culicoides from Panama (Diptera:Heleidae). Proc US Nat Mus 109: 237-482.
Wirth WW, Blanton FS 1973. A review of the maruins or biting midges of the genus Culicoides (Diptera:Ceratopogonidae) in the Amazon Basin. Amazoniana 4: 405-470.

Wirth WW, Blanton FS 1974. The West Indian sandflies of the genus Culicoides (Diptera:Ceratopogonidae). US Dept Agr Tech Bull 1474: 1-98.

Wirth WW, Dyce AL, Spinelli GR 1988. An atlas of wing photographs, with a summary of the numerical characters of the Neotropical species of Culicoides (Diptera: Ceratopogonidae). Contr Am Ent Inst 25: 1-72. 
